\title{
HOSPITAL PRACTICE
}

Description and discussion of organization, development and responses of parents to a newly created facility for ambulatory pediatric care.

\section{An Ambulatory Pediatric Unit}

\author{
Consumer's Satisfaction
}

F. J. DE CASTRO, M.D., M.P.H.,* H. AMIN, M.D.**

HERE is a national philosophic as well as a growing budgetary commitment to the belief that every child is entitled to comprehensive medical care of high quality.1-8 Concurrently, in response to numerous sociologic and medical stimuli, hospital outpatient clinics are becoming the only source of medical care for an increasing segment of the population. ${ }^{9-13}$ Unfortunately, services offered in hospital outpatient units are often fragmented. ${ }^{14,15}$ Modification of service units would seem a prerequisite, therefore, to offer comprehensive health service in hospital outpatient departments.

This report discusses the growth and transformation of a typical emergency room at a teaching county hospital into a comprehensive ambulatory pediatric unit. It consists of two parts: (1) a descriptive analysis of the unit; and (2) a quantitative study which measures consumer satisfaction with the medical services provided.

\section{Description of Pediatric Ambulatory Unit}

This was started with the following personnel: two full-time pediatricians, two nurses, one public health nurse, one secretary. Rotat-

From the Department of Pediatrics, University of Michigan and Wayne County General Hospital.

* Assistant Professor.

* Fellow.

Correspondence (F. J. de C.): Department of Pediatrics, University of Michigan, Ann Arbor, Mich. 48104. ing personnel-professional persons in training-were one pediatric resident, one intern, two junior medical students and two student nurses. During the second year of operation the number of full-time pediatricians was doubled. The number of nurses was increased to three registered nurses and three licensed practical nurses. One nutritionist and one audio-vision technician were added.

Two clinics were created: an acute care clinic and a diagnostic and evaluation clinic. During the second year a health supervision clinic for children five to 18 years old was started. Children less than five years old were followed for health supervision in the health department-established well-baby clinic, with our staff serving as consultant. Two satellite health supervision clinics for children up to 18 years old also were started during the second year of operation.

The unit serves mainly a low- to middlelevel socioeconomic population. Approximately half our infants and children qualify for a child and youth program sponsored by the Children's Bureau for medically indigent. The other half of the patients pay for their services directly or through private insurance.

The census rose from 667 per month to 2,166 per month during the two years ( $\mathrm{Ta}$ ble 1), along with a progressive increase in return visits for a specific illness. Age distribution can be seen in Table 2. These statistics do not include visits to our health depart- 


\section{DE CASTRO AND AMIN}

TABLe 1. Census of Patients, July 1, 1966 to June 30, 1968

\begin{tabular}{|c|c|c|c|c|}
\hline \multirow[b]{2}{*}{ Month } & \multicolumn{2}{|c|}{$\begin{array}{l}\text { July } 1,1966 \text { to } \\
\text { June } 30,1967\end{array}$} & \multicolumn{2}{|c|}{$\begin{array}{l}\text { July } 1,1967 \text { to } \\
\text { June } 30,1968\end{array}$} \\
\hline & $\begin{array}{l}\text { No. Patient } \\
\text { Visits } \\
\text { Per Month }\end{array}$ & $\begin{array}{l}\text { First } \\
\text { Visit* } \\
\text { Return } \\
\text { Visit }\end{array}$ & $\begin{array}{l}\text { No. Patient } \\
\text { Visits } \\
\text { Per Month }\end{array}$ & $\begin{array}{c}\text { First } \\
\text { Visit } \\
\text { Return } \\
\text { Visit }\end{array}$ \\
\hline July & 667 & 3 & 1,528 & 3.4 \\
\hline August & 988 & 3.5 & 1,653 & 2.5 \\
\hline September & 1,012 & 2.5 & 1,661 & 2.0 \\
\hline October & 1,189 & 3.0 & 1,789 & 2.1 \\
\hline November & 1,116 & 2.7 & 1,834 & 1.9 \\
\hline December & 967 & 3.3 & 2,131 & 2.0 \\
\hline January & 1,275 & 3.0 & 1,699 & 1.5 \\
\hline February & 1,340 & 2.3 & 1,757 & 1.6 \\
\hline March & 1,417 & 1.5 & 1,928 & 1.8 \\
\hline April & 1,334 & 2.4 & 1,788 & 1.8 \\
\hline May & 1,649 & 2.2 & 2,160 & 1.6 \\
\hline June & 1,445 & 2.9 & 2,031 & 1.6 \\
\hline Total & 14,399 & 2.6 & 21,965 & 1.9 \\
\hline
\end{tabular}

* First visit for a particular episodic or chronic illness. Return visit for illness.

ment well-baby clinic for children up to four years old which is covered by physicians from our team.

Tables 3 and 4 show diagnosis and dispositions made over the two years of clinic operation.

\section{Consumer's Satisfaction}

After one and one-half years of operation, this was measured by a questionnaire given to a random sample of 100 patients out of 5,384 clinic visits. The questionnaire attempted to measure general satisfaction by direct questioning and by an indirect slidingscale method with satisfaction set at 7 or above in a 0 -to-10 scale. Specific satisfaction with different members of the health team, and waiting times before seeing the doctor, were also questioned.

Direct questioning showed that 99 per cent of the patients were satisfied and the sliding- scale method showed 91 per cent. Difference is significant $(p<0.05)$ showing the greater sensitivity of the sliding-scale method. Consumer's satisfaction with different members of the health team can be seen in Table 5 . Satisfaction, both in general and with specific members of the health team, was high.

Waiting time before being seen by a doctor was less than half an hour with 59 per cent of the patients, one-half to one hour with 27 per cent, one to two hours with 14 per cent. No patient had to wait more than two hours.

\section{Comments}

Due to numerous medical and social reasons, hospital emergency rooms are being used increasingly as a source of regular medical care. ${ }^{11-15}$ This fact, plus an increased public awareness of the need to provide comprehensive care to all, is focusing medical attention on the quality of hospital outpatient facilities. ${ }^{17-19}$ Our ambulatory unit for infants and children is an attempt to provide comprehensive pediatric care through a hospital outpatient clinic.

Our goals include comprehensive and preventive care rather than solely episodic services, and community involvement also. Continuity of care was attempted through active participation of full-time pediatricians (for example, morning chart rounds were made to review all patients seen in the previous 24 hours) and home follow-up by the public health nurse.

Emphasis on preventive rather than on therapeutic services was attempted through extensive use of paramedical personnel. Nurses were made responsible for taking immunization histories, giving biologicals, and doing some screening laboratory procedures. Public health nurses worked with patients in the clinic and also visited in homes. The audio-vision technician, nutritionist and so-

TABLE 2. Age Distribution of Patients

\begin{tabular}{ccccccc}
\hline & \multicolumn{5}{c}{ Ages of Children (Years) } \\
\cline { 2 - 6 } Year & $0-1$ & $1-4$ & $5-9$ & $10-14$ & $15-18$ \\
\hline July 1, 1966 to June 30, 1967 & 2,120 & 5,412 & 3,235 & 2,451 & 1,181 \\
July 1, 1967 to June 30, 1968 & 2,883 & 7,341 & 5,625 & 3,979 & 2,137 \\
\hline
\end{tabular}


AN AMBULATORY PEDIATRIC UNIT

TABLE 3. Diagnosis and Disposition of Patienis Seen from July 1, 1966 to June 30, 1967

\begin{tabular}{|c|c|c|c|c|c|c|c|}
\hline \multirow[b]{2}{*}{ Diagnosis } & \multirow[b]{2}{*}{ Total } & \multicolumn{6}{|c|}{ Disposition } \\
\hline & & $\begin{array}{l}\text { Return } \\
\text { Visit } \\
\text { Scheduled }\end{array}$ & $\begin{array}{l}\text { Health } \\
\text { Super- } \\
\text { vision* }\end{array}$ & $\begin{array}{l}\text { Referred } \\
\text { to Sub- } \\
\text { specialty }\end{array}$ & $\begin{array}{l}\text { Called } \\
\text { for } \\
\text { Report*** }\end{array}$ & $\begin{array}{l}\text { Admitted } \\
\text { to } \\
\text { Hospital }\end{array}$ & Others \\
\hline Infective and parasitic diseases & 533 & 212 & 227 & 38 & 12 & 44 & \\
\hline Neoplastic diseases & 3 & & 1 & 6 & & 1 & \\
\hline Allergic diseases & 550 & 202 & 154 & 144 & 1 & 48 & 1 \\
\hline Endocrine, metabolic and nutritional diseases & 131 & 75 & 16 & 25 & 3 & 12 & \\
\hline Diseases of blood & 183 & 93 & 31 & 34 & 2 & 23 & \\
\hline $\begin{array}{l}\text { Mental, psychoneurotic and personality } \\
\text { disorders }\end{array}$ & 292 & 91 & 68 & 120 & & 13 & \\
\hline Diseases of nervous system and sense organs & 560 & 165 & 134 & 180 & 2 & 75 & 4 \\
\hline Diseases of circulatory system & 168 & 70 & 37 & 38 & 1 & 24 & \\
\hline Diseases of respiratory system & 6,133 & 3,302 & 2,101 & 419 & 21 & 275 & 15 \\
\hline Diseases of digestive system & 1,622 & 501 & 589 & 400 & 18 & 105 & 9 \\
\hline Disease of genitourinary system & 465 & 233 & 70 & 103 & 4 & 34 & 1 \\
\hline Complications of pregnancy & 14 & 2 & 4 & 7 & & 1 & \\
\hline Skin diseases & 1,622 & 932 & $45 i$ & 167 & 2 & 59 & 11 \\
\hline Diseases of bones and organs of movement & 205 & 56 & 85 & 55 & & 9 & \\
\hline Congenital malformations & 44 & 14 & 6 & 6 & 2 & 16 & \\
\hline Diseases of early infancy & 60 & 22 & 28 & 3 & 1 & 5 & 1 \\
\hline Healthy patient and other & 1,118 & 236 & 651 & 103 & 14 & 58 & 56 \\
\hline $\begin{array}{l}\text { Injuries, adverse effects of chemical and } \\
\text { other external agents }\end{array}$ & 1,560 & $\$ 12$ & 850 & 110 & 7 & 79 & 9 \\
\hline
\end{tabular}

* For health surveillance and immunization.

** Patient asked to return for further diagnostic or therapeutic intervention because of abnormal laboratory report.

TABLE 4. Diagnosis and Disposition of Patients Seen from July 1, 1967 to June 30, 1968

\begin{tabular}{|c|c|c|c|c|c|c|c|}
\hline \multirow[b]{2}{*}{ Diagnosis } & \multirow[b]{2}{*}{ Total } & \multicolumn{6}{|c|}{ Disposition } \\
\hline & & $\begin{array}{c}\text { Return } \\
\text { Visit } \\
\text { Scheduled }\end{array}$ & $\begin{array}{l}\text { Health } \\
\text { Super- } \\
\text { vision }\end{array}$ & $\begin{array}{l}\text { Referred } \\
\text { to Sub- } \\
\text { specialty }\end{array}$ & $\begin{array}{c}\text { Called } \\
\text { for } \\
\text { Report }\end{array}$ & $\begin{array}{l}\text { Admitted } \\
\text { to } \\
\text { Hospital }\end{array}$ & Others \\
\hline Infective and parasitic diseases & 1,150 & 836 & 226 & 46 & 5 & 36 & 1 \\
\hline Neoplastic diseases & 50 & 21 & 8 & 10 & & 11 & \\
\hline Allergic diseases & 970 & 687 & 145 & 96 & & 40 & 2 \\
\hline Endocrine, metabolic and nutritional diseases & 511 & 425 & 18 & 42 & & 24 & 2 \\
\hline Diseases of blood & 386 & 304 & 34 & 21 & 3 & 24 & \\
\hline Mental, psychogenic and personality disorders & 1,458 & 1,232 & 117 & 92 & 4 & 12 & 1 \\
\hline Diseases of nervous system and sense organs & 1,227 & 649 & 111 & 390 & 1 & 74 & 2 \\
\hline Diseases of circulatory system & 260 & 156 & 39 & 46 & 1 & 18 & \\
\hline Diseases of respiratory system & 8,986 & 5,743 & 2,656 & 371 & 5 & 202 & 9 \\
\hline Diseases of digestive system & 2,712 & 994 & 739 & 879 & 14 & 91 & 5 \\
\hline Diseases of genitourinary system & 763 & 547 & 70 & 110 & 2 & 31 & 3 \\
\hline Complications of pregnancy & 14 & 3 & 2 & 9 & & & \\
\hline Skin diseases & 2,275 & 1,748 & 371 & 108 & 1 & 39 & 5 \\
\hline Diseases of bones and organs of movement & 331 & 179 & 65 & 75 & & 12 & \\
\hline Congenital malformations & 168 & 106 & 11 & 35 & 1 & 15 & \\
\hline Diseases of early infancy & 76 & 42 & 31 & 3 & & & \\
\hline Healthy patient and others & 2,849 & 1,106 & 1,335 & 194 & 5 & 107 & 102 \\
\hline $\begin{array}{l}\text { Injuries and adverse effects of chemical and } \\
\text { other external agents }\end{array}$ & 2,007 & 1,100 & 737 & 84 & 2 & 78 & 6 \\
\hline
\end{tabular}




\section{DE CASTRO AND AMIN}

TABLE 5. Consumer's Salisfaction with

Different Members of the Heallh Team.

\begin{tabular}{lcccc}
\hline $\begin{array}{c}\text { Degree of } \\
\text { Satisfaction }\end{array}$ & $\begin{array}{c}\text { Nurse's } \\
\text { Han- } \\
\text { dling }\end{array}$ & $\begin{array}{c}\text { Doctor's } \\
\text { Explan- } \\
\text { ation }\end{array}$ & $\begin{array}{c}\text { Doctor's } \\
\text { Handling }\end{array}$ & $\begin{array}{c}\text { Nutrition- } \\
\text { ist Explan- } \\
\text { ation }\end{array}$ \\
\hline $\begin{array}{l}\text { Satisfied } \\
\text { Dissatisfied }\end{array}$ & 98 & 97 & 100 & 95 \\
$\begin{array}{c}\text { Somewhat } \\
\text { dissatisfied }\end{array}$ & 2 & 2 & 0 & 0 \\
\hline
\end{tabular}

cial workers participated in their specialized areas of service.

Public health nurses and school social workers did follow-up work in the community. Contact was established with the school system and referral procedures for school-age children were established.

Development of the unit was facilitated by available service resources which were similar to those available in most teaching hospitals. These were: well-baby clinic, subspecialty medical and surgical clinics, inpatient facilities, and in-training services for rotating personnel. Subspecialty facilities were adequate except for psychologic problems; here the great prevalence of behavior disorders in the population made it necessary for the fulltime pediatricians to start a behavior clinic to supplement the guidance counseling unit.

Growth of the unit in terms of services made available to the population served and of the patient volume was considerable. However, such growth of itself may not be related to satisfaction of the patients served.

Consumer satisfaction has been an important parameter measured to evaluate new forms of medical care ${ }^{20}$ and, as shown, consumer satisfaction in our unit was high. Several factors were probably responsible for the high degree of satisfaction: (1) presence of the permanent professional staff; (2) multiple facilities available to the clinic (inpatient service, subspecialty clinics); (3) appointment system for all nonacute or diagnostic visits; and (4) improved registration procedures by use of the telephone to preregister all patients with scheduled appointments.

Units such as the one described probably offer an effective approach to cope with the shortage of health manpower in providing complete care. The effectiveness of such units should be further studied through other variables such as communication with patients, broken appointment rates, and morbidity and mortality in the population served.

\section{References}

1. Bashchur, R. L., Metzner, C. A. and Worden, C.: Consumer's satisfaction with group practice; the CHA case. Amer. J. Public Health 57: 1991 , 1967.

2. Brown, B. S.: Letter to the editor. New Eng. J. Med. 258: 507, 1958.

3. Cherkosky, M.: Resources needed to meet effectively expanded demands for service. Bul. N. Y. Acad. Med. 42: 1089, 1966.

4. Darley, W. and Somers, A.: Medicine, money and manpower; I. the affluent new health care economy; II. opportunity for new excellence; III. increasing personnel; IV. new training for new needs. New Eng. J. Med. 276: 1234, 1291, 1414, 1967.

5. Department of Hospitals and Medical Facilities: Emergency department problems; overview. JAMA 198: $380,1966$.

6. Dunlop, J. T.: Capacity of the United States to provide and finance expanding health service. Bul. N. Y. Acad. Med. 41: 1325, 1965.

7. Fuchs, V. R.: The growing demand for medical care. New Eng. J. Med. 279: 191, 1968.

8. Gardner, J. W.: Great move forward. Presented at White House Conference on Health, Washington, D. C., November 3, 1965.

9. Korsch, B. M.: Pediatric outpatient departments. Pediatrics 23: 162, 1959.

10. Kortman, L.: Human ecology and public health. Amer. J. Public Health 57: 731, 1967.

11. Parson, T. and Fox, R. C.: Illness, therapy and modern urban American family. J. Social Issues 8: $31,1952$.

12. Schaffer, A. J.: A community-aid pediatric program; a beginning and a blueprint for the future. Pediatrics 36: $429,1965$.

13. Solon, J. A., Sheps, C. G., Lee, S, S. and Barbaro, J. P.: Pattern of medical care; validity of interview information on use of hospital's clinics. J. Health Hum, Behav. 3: 21, 1962.

14. Torrens, P, R. and Yedvab, D. C.: The impact of emergency services upon patterns of ambulatory care. St. Luke's Hospital. New York City, August 1965.

15. Wallace, H. M.: Community Medical Care Facilities for Children in Ambulatory Pediatrics. Philadelphia, W. B. Saunders, 1968, p. 81.

16. Weinermann, E. R., Ratner, R. S., Robins, A. and Lovenbar, M. A.: Yale studies in ambulatory medical care; $V$. determinants of use of hospital emergency service. Amer. J. Public Health 56 : $1037,1966$.

17. Weinermann, E. R.: Yale studies in ambulatory medical care; IV. outpatient clinic services in a teaching hospital. New Eng. J. Med. 258: 507,1958

18. White, K. L., Williams, T. F. and Greenberg, B. C.: The ecology of medical care. Ibid. 265: 885 , 1961 . 